\title{
Is the Charlottenthal fan (marginal zone of the Pomeranian phase, NE Germany) an end moraine?
}

\author{
Małgorzata Pisarska-Jamroży ${ }^{* 1} \&$ Andreas Börner ${ }^{2}$ \\ ${ }^{1}$ Institute of Geology, Adam Mickiewicz University, Maków Polnych 16, 61-606 Poznań, Poland; \\ e-mail: pisanka@amu.edu.pl \\ ${ }^{2}$ State Authority of Environment, Nature Protection and Geology Mecklenburg-Western Pomerania, Goldberger \\ Strasse 12, 18273 Güstrow, Germany; e-mail: andreas.boerner@lung.mv-regierung.de \\ * corresponding author
}

\begin{abstract}
The maximum ice-sheet extent of a glaciation or glacial phase is in most cases indicated by the position of end moraines. In some cases, however, the maximum extent of the ice sheet is indicated by a fan which represents the transitional zone between the end moraine and the proximal outwash plain (sandur). Such a fan from the Pomeranian phase near Charlottenthal in NE Germany has been investigated for its lithofacies, and the depositional mechanisms of the two sedimentary environments (end moraine and outwash plain) are reconstructed. The Charlottenthal profile is not characteristic in a sedimentological sense of a typical marginal end moraine or a sandur. The deposits represent subaerial debris flows, sheet floods and channelized currents, which are typically processes for transitional fan.

Gravel samples from the till complex show typical Weichselian till compositions. These till compositions indicate a general transport direction from North to South, which is consistent with the known movement of the ice sheet during the Pomeranian phase of the Weichselian.
\end{abstract}

Keywords: transitional fan, glaciofluvial sediments, gravel petrography, Weichselian glaciation, Pomeranian Phase, NE Germany

\section{Introduction}

The change of the sediments of the Charlottenthal fan (Fig. 1) from proximal (ice-contact) to distal has been investigated sedimentologically. The main objective was to reconstruct the depositional processes and, finally, to compare the deposits and depositional mechanisms with fan models for glaciomarginal zones (Woldstedt, 1961; Flint, 1971; Blair \& McPherson, 1994; Krzyszkowski \& Zieliński, 2002; PisarskaJamroży, 2006). An additional objective was to establish gravel indicators which can help re- construct the main ice-flow directions during the Pomeranian ice advance.

Woldstedt (1961) and Flint (1971) described end moraines as forms consisting mainly of tills or reworked tills (flowtills) with only subordinate amounts of sorted sediments. Krzyszkowski and Zieliński (2002) indicated three kinds of fan-type end moraine: (1) those consisting mainly of mass-flow deposits, (2) those consisting of sorted glaciofluvial (and possibly glaciolacustrine) deposits, and (3) a mixture of (1) and (2). Pisarska-Jamroży (2006) described such fan-type end moraines (which we call 


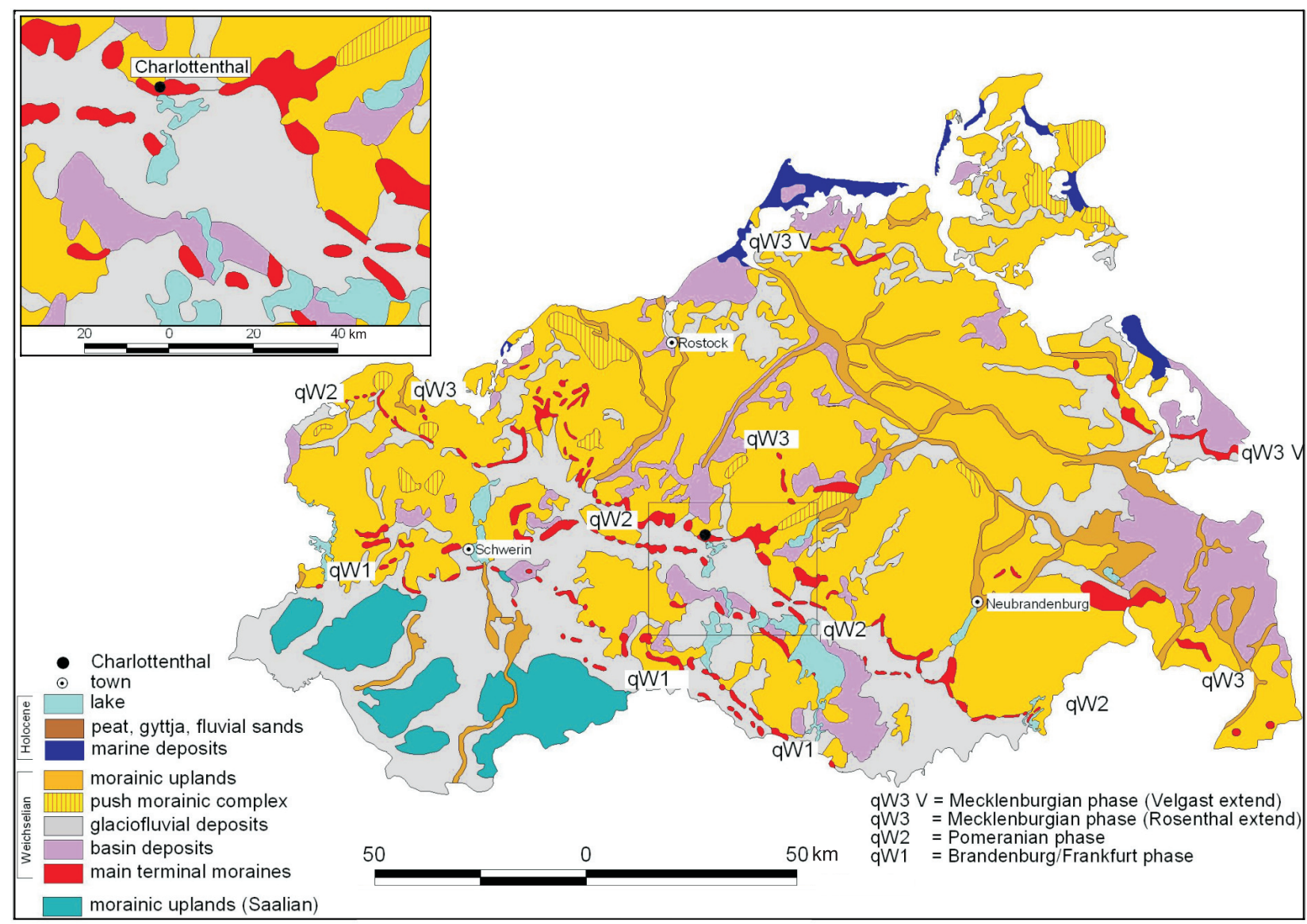

Fig. 1. Distribution of the various types of Quaternary deposits in the vicinity of Charlottenthal (from Börner, 2010; modified from Bremer, 2000).

'transitional fans' in the following) as smallscale glaciomarginal forms similar to end moraines, but consisting of gravelly diamictons derived from debris flows, sandy diamictons derived from hyperconcentrated flows, alternating sands and gravels deposited by sheetfloods, and sandy deposits filling shallow, braided-stream channels. We show also gravel petrographic indicators which can help in reconstruction of mean ice-flow directions during the Pomeranian ice advance.

\section{Geological and geomorphological setting}

The various phases of advance and retreat of the Weichselian ice sheet all left their own tills in NE Germany (Rühberg et al., 1995). During the Weichselian glaciation, the Pleniglacial began with the Brandenburg/Frankfurt advance

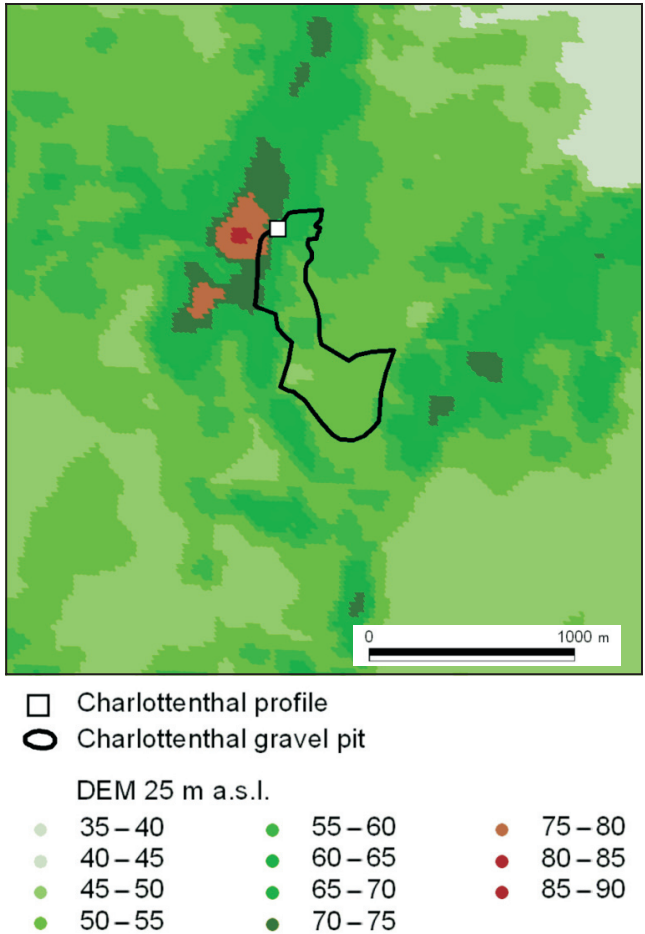

Fig. 2. Digital elevation model (DEM) of the Charlottenthal area. 
(qW1 in Fig. 1). The following, stepwise, deglaciation was interrupted by at least two substantial ice re-advances, known as the Pomeranian advance (qW2 in Fig. 1) and the Mecklenburgian advance (qW3 in Fig. 1).

The Charlottenthal gravel pit is situated between the ice-terminal zone - including the meltwater drainage systems - in the North and the outwash plain in the South. Most landforms and sediments around the pit date from the main Pomeranian ice advance. The retreating ice left a mosaic of hummocky morainecovered uplands directly behind the Pomeranian terminal moraines and the large outwash plains south of them (Fig. 1). Schulz (1962) described a numerical order of 17 varying terminal moraine ridges, as evidence for the regional oscillations during the Pomeranian ice retreat. According to an ice-retreat model of Schulz (1963), the area of the Charlottenthal gravel pit owes its shape mainly to the terminal-moraine ridges of oscillations no. 7 and no. 8. Particularly in the eastern, but also in the western part of Charlottenthal, the Pomeranian terminal moraine has a lobe-like morphology. Because of these surrounding lobe structures, the central - N-S elongated - hillocks in the western part of the pit may represent a local inter-lobe structure (cf. Fig. 2 \& 3).
In the study area, the elevations of the ridgeshaped, till-covered terminal moraines vary mostly between 55 and $80 \mathrm{~m}$ a.s.l. (Fig. 1). In the northern part of the outcrop $(\sim 70 \mathrm{~m}$ a.s.l.: Fig. 4), an upper till of 1-6 $\mathrm{m}$ thick covers glaciofluvial sands and gravelly sands (GFE, 2000). The glaciofluvial gravels and sands were detected in several drillings between $64-35 \mathrm{~m}$ a.s.l. (GFE, 2000). The upper till is wedging out towards the South, so that the glaciofluvial sediments become exposed at the undulating surface in the southern part of the outcrop (Fig. 2). These gravelly sands in the undulating terrain were mapped by Schulz (1962) as glaciofluvial gravelly sands of the end moraines ('kiesiger Schmelzwassersand der Endmoräne'). In the Charlottenthal region the meltwater flowed to the SW and S during the deglaciation of the Pomeranian ice sheet (Schultz, 1962).

\section{Lithofacies associations}

The sediments in the pit consist of sands, gravels and diamicts. The sands and gravels are coded following Miall (1985), Zieliński (1993) and Pisarska-Jamroży (2006), whereas the diamicts are coded following Krüger \& Kjær (1999) (Table 1). The various lithofacies

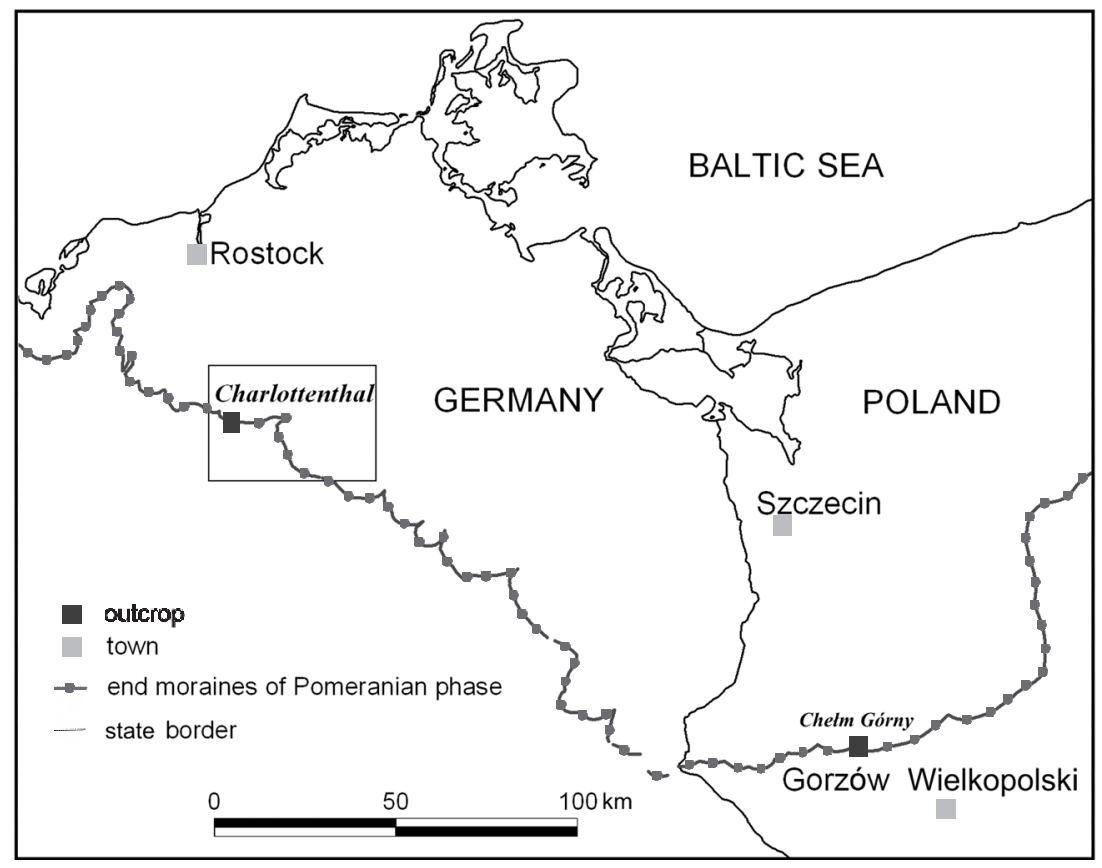

Fig. 3. Location of the Charlottenthal and Chełm Górny sites in relation to the maximum extent of the ice during the Pomeranian phase in NE Germany and NW Poland. 
Table 1. Lithofacies code symbols used in the present study, following Miall (1985), Zieliński (1993), Pisarska-Jamroży (2006) and Krüger \& Kjær (1999).

\begin{tabular}{|c|c|c|c|c|}
\hline \multicolumn{2}{|c|}{ Code } & \multicolumn{2}{|c|}{ Grain size } & Structure \\
\hline \multicolumn{4}{|l|}{ Sh } & horizontal stratification \\
\hline \multicolumn{2}{|l|}{ Sp } & \multirow{2}{*}{\multicolumn{2}{|c|}{ sand, fine to very coarse }} & planar cross-stratification \\
\hline St & & & & trough cross-lamination \\
\hline \multicolumn{4}{|l|}{ Src } & ripple-drift cross-lamination \\
\hline \multirow{3}{*}{$\mathrm{Gm}$} & GRm & & granule gravel & \\
\hline & GPm & gravel & pebble gravel & massive \\
\hline & GCm & & cobble gravel & \\
\hline \multicolumn{2}{|c|}{$\operatorname{DmC}\left(\mathrm{m}_{2}\right)$} & $\begin{array}{l}\text { diamic } \\
\text { with sa }\end{array}$ & trix-supported & massive \\
\hline
\end{tabular}

and lithofacies associations are coded in the same way.

The deposits constitute two lithofacies associations (Fig. 4): (1) trough- and planar crossstratified sands (St, Sp) and (2) massive heterolithic gravels and horizontally laminated sands (Gm, Sh), and one lithofacies, viz. a massive, coarse diamict, $\mathrm{DmC}\left(\mathrm{m}_{2}\right)$.

\subsection{Lithofacies association St, Sp}

\subsubsection{Description}

This lithofacies association (Fig. 4 D-E) occurs in the lower part of the outcrop. Its exposed part is $\sim 4 \mathrm{~m}$ thick and it has a horizontal extent of $\sim 100 \mathrm{~m}$. The individual layers are mostly lenticular but sometimes sheet-like, with thicknesses between $50 \mathrm{~cm}$ (lithofacies $\mathrm{Sp}$ ) and $160 \mathrm{~cm}$ (lithofacies St). Both lithofacies consist of medium- and coarse-grained sands. Some layers contain an admixture of fine gravel. The lower and upper boundaries of both lithofacies tend to be sharp and erosional. The laminae in lithofacies Sp dip 5-15 $5^{\circ}$ towards the SE to $S$, and the average depth of the troughs of lithofacies St amounts to some $5-25 \mathrm{~cm}$.

\subsubsection{Interpretation}

Lithofacies St represents migrating sandy 3-D dunes, which implies a current of the upper part of the lower flow regime. The average depth of the braided channels was $10-50 \mathrm{~cm}$ (following the calculation method of Mohrig et al., 2000). Lithofacies Sp represents migrating sandy, straight-crested (2-D) dunes, which indicates a turbulent current in the middle part of the lower flow regime. Deposition of both Sp and St laminae took place on a surface dipping $5-15^{\circ}$ towards the SE to $S$, which indicates deposition on a fan. The Sp and St sands were deposited by a current with similar directions.

The sandy cross-bedded sediments point to distal braided rivers such as the Platte River (Smith, 1970; Miall, 1978), to $9^{\text {th }}$-type and $10^{\text {th }}$ type braided channels (Miall, 1985), to the D3/ D4 lithotype of Zieliński (1993), and to the B and $C$ end-moraine fans of Krzyszkowski \& Zieliński (2002). Lithofacies association St, Sp thus represents shallow braided-stream channels (the sets of small- and medium-scale crossstratified sands are interpreted as bars formed during more or less average discharge).

\subsection{Lithofacies association $\mathrm{Gm}$, Sh}

\subsubsection{Description}

This lithofacies association is present in the middle part of the outcrop (Fig. 4 C, E). Its exposed part is $\sim 1-3 \mathrm{~m}$ thick and it is $\sim 100 \mathrm{~m}$ wide. Subordinate lithofacies of this association are planar, trough and ripple-drift crossbedded sands (lithofacies Sp, St, Src).

The layers of this lithofacies association form sheets, with thicknesses up to $15 \mathrm{~cm}$ (lithofacies Sh), $30 \mathrm{~cm}$ (lithofacies GRm), $40 \mathrm{~cm}$ (lithofacies GPm) and $70 \mathrm{~cm}$ (lithofacies GCm). All gravelly lithofacies consist of gravels with an admixture of medium- and coarse-grained sand. The lower and upper boundaries of the gravelly lithofacies are gradual. The granule- 
sized gravel (lithofacies GRm) and the pebbly gravel (lithofacies GPm) are matrix-supported, whereas the cobbly gravel (lithofacies GCm) is clast-supported. Characteristic features of the three gravelly massive lithofacies (GRm, GPm and $\mathrm{GCm}$ ) is the very good rounding of the clasts and the rhythmical alternation of sand and massive gravel.
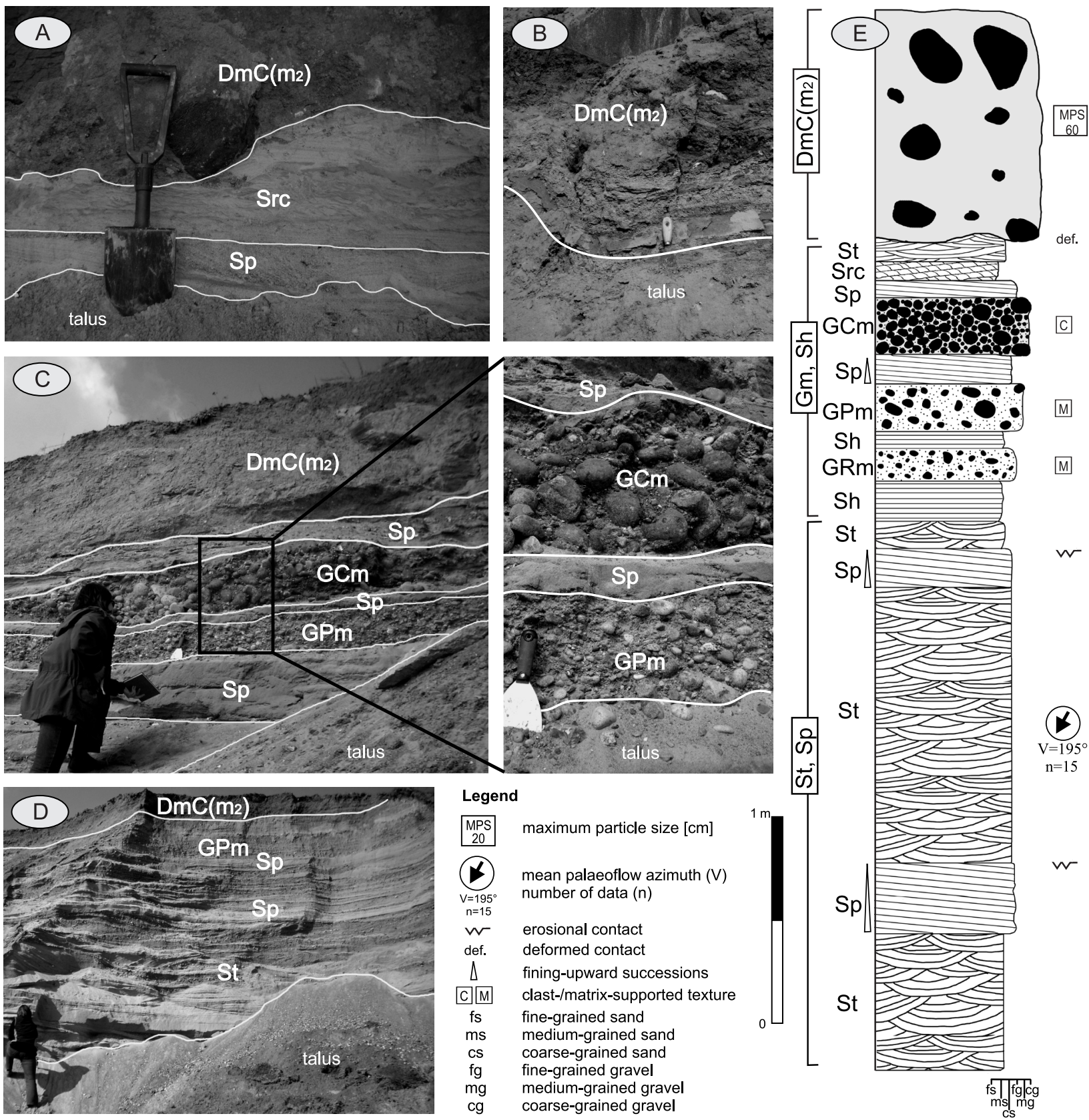

maximum particle size $[\mathrm{cm}]$

mean palaeoflow azimuth $(\mathrm{V})$ number of data $(n)$

erosional contact deformed contact

fining-upward successions clast-/matrix-supported texture fine-grained sand medium-grained sand coarse-grained sand fine-grained gravel medium-grained gravel coarse-grained gravel
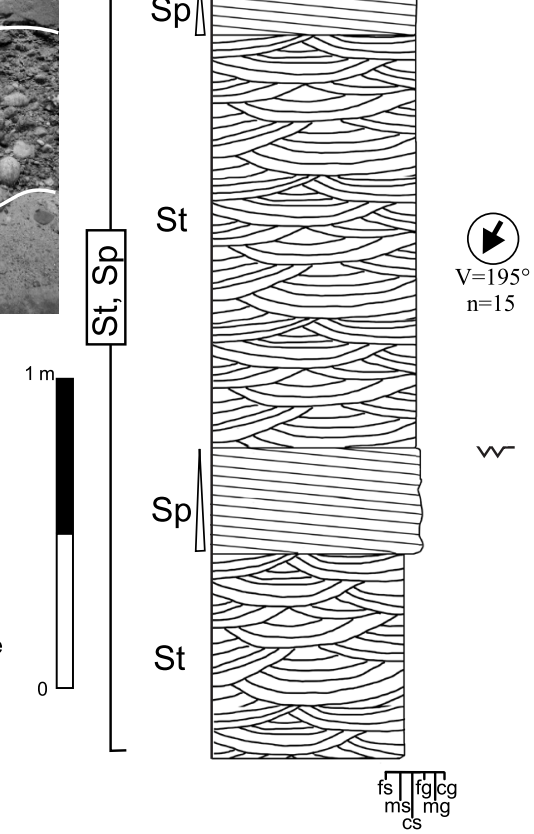

Fig. 4. Details of the sections of the Charlottenthal fan.

A - Planar and ripple-drift cross-bedded sands (Sp, Src) of the $\mathrm{Gm}$, Sh lithofacies association, and upper lithofacies of the massive gravelly diamicton $\operatorname{DmC}\left(\mathrm{m}_{2}\right)$; $\mathbf{B}$ - Massive gravelly diamicton $\operatorname{DmC}\left(\mathrm{m}_{2}\right)$ with angular clasts (maximum size $60 \mathrm{~cm}$ ); C - Planar cross-bedded sands (Sp) and massive pebble and cobble gravels (GPm and GCm) in the Gm, Sh lithofacies association, and upper lithofacies of the massive gravelly diamicton, $\mathrm{DmC}\left(\mathrm{m}_{2}\right)$; $\mathrm{D}-\mathrm{Trough}-$ and planar cross-stratified sands of the St, Sp association, and planar cross-stratified sand (Sp) and massive pebble gravels (GPm) of the Gm, Sh lithofacies association, massive coarse-grained diamicton of lithofacies $\mathrm{DmC}\left(\mathrm{m}_{2}\right) ; \mathbf{E}$ - Synthetic log of the proximal Charlottenthal fan: the association with trough- and planar cross-stratified sands (St, Sp), the association with massive gravels and horizontally laminated sands (Gm, Sh), and the massive coarsegrained diamicton $\mathrm{DmC}\left(\mathrm{m}_{2}\right)$. 


\subsubsection{Interpretation}

The Gm, Sh association indicates currents with an upper flow regime (Harms et al., 1982), with plane-bed deposition. Such deposits represent shallow, short-lived currents of sheetflood type (cf. McKee et al., 1967; Miall, 1977). The alternations of sand and gravel are due to pulses in the current power. The textural differences and the changes in thickness reflect short-term fluctuations in sediment supply, possibly due to seasonal (or shorter) changes in the ablation rate. The gravelly beds were deposited during peaks in the discharge, whereas the sandy layers indicate phases of lower discharge. The cross-stratified lithofacies Sp, St and Src were formed in a shallow channel with ephemeral, low-energy currents.

The Gm, Sh association is characteristic of lithotype P-2 in proximal glaciomarginal fans (Zieliński, 1992) and in transitional fans (Pisarska-Jamroży, 2006), and reflect shortterm changes in the ablation of the ice sheet.

\subsection{Lithofacies $\operatorname{DmC}\left(m_{2}\right)$}

\subsubsection{Description}

The lithofacies consisting of massive, gravelly diamicton, $\operatorname{DmC}\left(\mathrm{m}_{2}\right)$, is exposed in the upper part of the outcrop (Fig. 4 A, B, E). It is 0.6-1.7 $\mathrm{m}$ thick and extends laterally over 150 $\mathrm{m}$. The lower boundary with lithofacies association Gm, Sh is deformed (Fig. 4 A, E). The diamicton is commonly matrix-supported; the matrix consists of sand with an admixture of silt and clay. The clasts are angular and are on average about $30 \mathrm{~cm}$ long (up to $60 \mathrm{~cm}$ ). Diffuse pseudostratification is present and flexural folds occur at the base. The folds have amplitudes of approx. $15 \mathrm{~cm}$ and a horizontal extent of up to a metre (Fig. 4 B).

\subsubsection{Interpretation}

Lithofacies $\operatorname{DmC}\left(\mathrm{m}_{2}\right)$ was deposited by debris flows (flowtills), which deformed the underlying lithofacies association St, Sp. The deposition by debris flows is evidenced by the massive structure, the matrix-supported texture, and the bad sorting (from clay to cobbles and boulders) (cf. Sharp \& Nobles, 1953; Scott,
1971; Nemec \& Steel, 1984). The vague pseudostratification that is locally present at the base of some $\operatorname{DmC}\left(\mathrm{m}_{2}\right)$ layers can be attributed to the segregation of particles by the basal laminar shear in the debris flows (Johnson \& Rodine, 1984; Nemec \& Steel, 1984). Compression, as reflected by the occasional occurrence of folds can also occur during debris-flow deposition (Johnson \& Rodine, 1984; Nemec, 1990).

Gravelly diamictons are considered to represent an 'ice-slope zone'. Zieliński (2003) considered such deposits to indicate the proximity of an ice margin and the formation of end moraines. Flowtills are typical of the glaciomarginal environment, where debris flows predominate and build end moraines and ice-contact fans (Kasprzak, 1988; Zieliński, 1992; Zieliński \& Van Loon, 1996; Pisarska-Jamroży, 2008), A and B fans (sensu Krzyszkowski \& Zieliński, 2002), fans of type I (sensu Blair \& McPherson, 1994), and debris-flow fans (Harvey, 1984), and can also result in the construction of transitional fans (Pisarska-Jamroży, 2006, 2008).

\section{Gravel petrography}

Börner \& Müller (2009) used, for their petrographical classification of till samples from the Charlottenthal gravel pit, a pebble-counting method for till clasts of $4-10 \mathrm{~mm}$ that was slightly modified after TGL 25 232/1-6 (1980). The samples from the till complex in this pit show gravel compositions (Fig. 5) with a high content of sandstones and quartzites (S > 10\%) and Palaeozoic shales (PS $\sim 4-10 \%$ ). Remarkable are the relatively large amounts of Mesozoic limestones, mainly Cretaceous marls (MK $\sim 5-8 \%$ ) and Cretaceous flints ( $F \sim 3-6 \%)$. The limestone clasts and Cretaceous marls frequently show distinct weathering.

The petrographical compositions of the till in the Charlottenthal pit have been described by Górska-Zabielska (2008). Her analysis of the till clasts and glaciofluvial gravel was limited to the $5-10 \mathrm{~mm}$ size, following the Polish counting standard (Instrukcja, 1996), and shows the presence of Nordic crystallines (NK 40\%), sandstones and quartzites ( $\sim 18 \%)$, a remarkably high content of Cretaceous flints ( $\mathrm{F} \sim 11 \%$ ) 


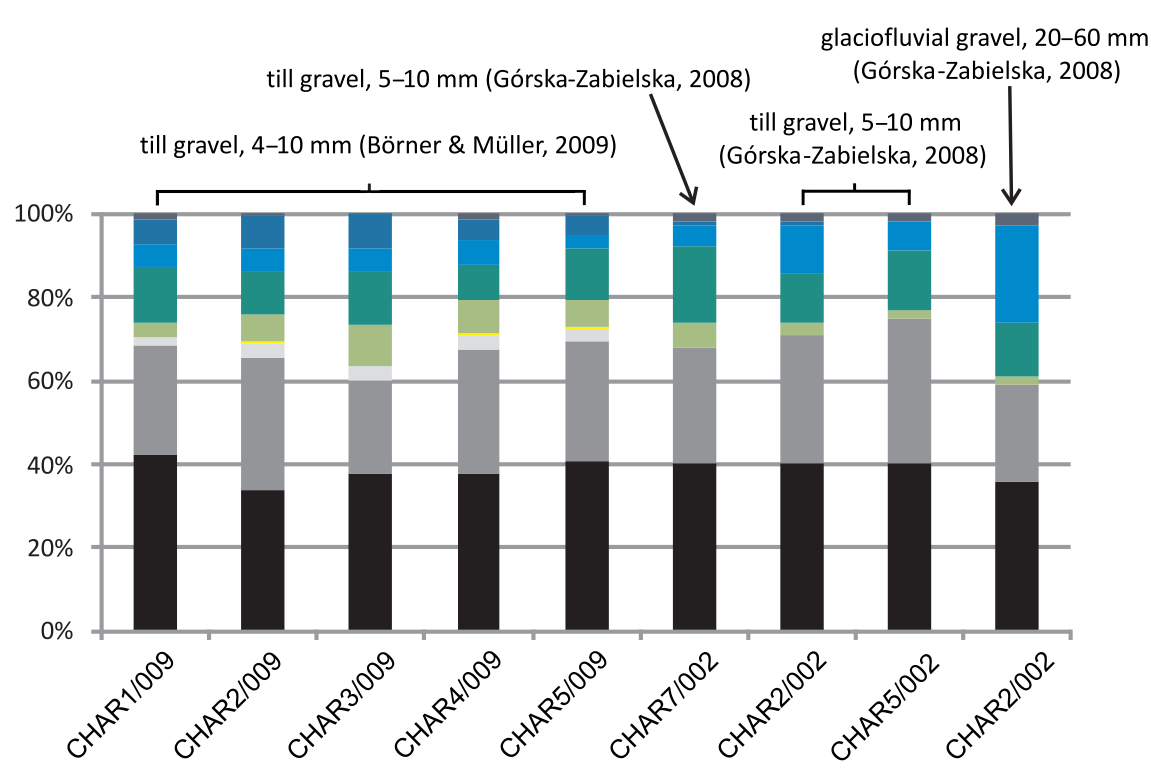

Fig. 5. The petrographical groups of till clasts and glaciofluvial deposits from the Charlottenthal gravel pit. NC - Northern crystalline rocks; PL1 - grey Palaeozoic limestones; PL2 red Palaeozoic limestones; D - dolomites; PS - Palaeozoic shales; S - Scandinavian sandstones and quartzites; F - Cretaceous flints; $\mathrm{M}$ - Cretaceous marls; Q - quartz.

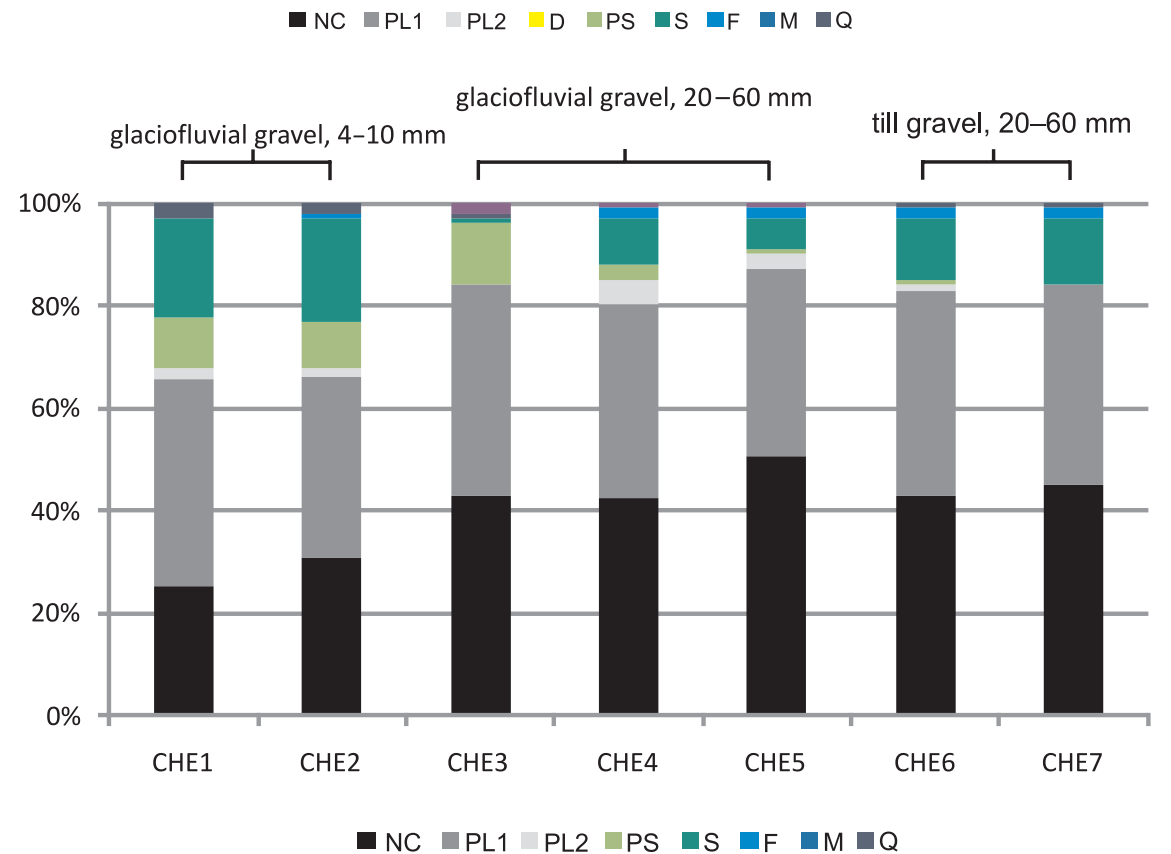

Fig. 6. The petrographical groups of till clasts and glaciofluvial deposits from the Chełm Górny gravel pit (from Górska-Zabielska \& PisarskaJamroży, 2008). NC - Northern crystalline rocks; PL1 - grey Palaeozoic limestones; PL2 - red Palaeozoic limestones; PS - Palaeozoic shales; $S$ - Scandinavian sandstones and quartzites; F - Cretaceous flints; M - Cretaceous marls; $Q$ - quartz; L - lydite.

and smaller amounts of less indurated rocks like Palaeozoic shales (PS 3\%), calcareous rocks like Palaeozoic limestones (PK 28\%) and Cretaceous marls (MK $1 \%$ ).

The petrographical analysis of two 5-10 $\mathrm{mm}$ samples from Charlottenthal (GórskaZabielska, 2008), taken from massive glaciofluvial gravels, shows a relatively large amount of hard-rock clasts such as Northern crystallines (NK $\sim 40 \%$ ), Palaeozoic limestones (PK 31$35 \%)$ and sandstones and quartzites (S 16\%), but significantly smaller amounts of softer rocks such Palaeozoic shales (PS 2-3\%) and
Cretaceous marls (MK $\sim 0-1 \%$ ). Sample Charlottenthal 2/2002 (20-60 mm) shows an abnormal enrichment in Cretaceous flints ( $F \sim 23 \%$ ). The indicator-pebble analysis (TGZ-method, after Lüttig, 1958) of 20-60 $\mathrm{mm}$ pebbles by Górska-Zabielska (2008) indicates south-western Sweden (Dalarna, Småland and Skåne) as the main source area, with a theoretical central position at $58.5^{\circ} \mathrm{N}$ and $15.1^{\circ} \mathrm{E}$.

The petrography of the Pleistocene gravels (4-10 $\mathrm{mm})$ in the glaciofluvial deposits at Chełm Górny (Fig. 6) has been investigated by GórskaZabielska \& Pisarska-Jamroży (2008). Samples 
CHE1 and CHE2 comprise three dominant petrographical groups within the gravels: Lower Palaeozoic limestones, northern sandstones and Palaeozoic shales. Remarkable is the large amount of Palaeozoic shales (PS 9-10\%). The sedimentary rocks are distinctly more frequent than the hard rocks like crystallines, quartz and flint. The pebbles in samples CHE3-CHE5, consisting of glaciofluvial pebbles, differ petrographically clearly from the smaller clasts in the same layers. Sedimentary rocks like Lower Palaeozoic limestones, northern sandstones and Palaeozoic shales dominate in samples CHE3 and CHE4. In sample CHE3, a maximum value was found for Palaeozoic shales (PS 12\%). The pebbles of samples CHE6 and CHE7 (20-60 mm) were taken from the till. The indicator-pebble analysis (carried out in the same way as for Charlottenthal) shows southeastern Sweden (Dalarna, Småland and Åland islands) as the main source area. The theoretical gravel centre is located at $57.7^{\circ} \mathrm{N}$ and $16.0^{\circ}$ E in Småland (Górska-Zabielska, 2008), so that the ice flow was roughly from NNE to SSW.

\section{The Charlottenthal fan as an example of a 'transitional fan'}

Three groups of deposits are distinguished in the Charlottenthal pit: (1) a diamicton deposited by debris flows (a massive, matrix-supported, coarse-grained diamicton with a matrix of sand and fine gravel), (2) gravelly to sandy layers deposited by sheetfloods (massive gravels and horizontally laminated sands), and (3) sands deposited in a braided channel (troughand planar cross-stratified sand). The glaciomarginal deposits in the Charlottenthal area were formed during three phases. The lower association (St, Sp) accumulated in quite shallow braided-stream channels in the middle/ distal part of a sandur. The Gm, Sh association indicates deposition by sheetfloods with shortterm fluctuations in discharge, in combination with slightly cohesive debris-flow deposits, $\operatorname{DmC}\left(\mathrm{m}_{2}\right)$, in the ice-contact zone.

Sediments similar to the debris-flow and sheetflood deposits from the proximal part of
Charlottenthal pit have been reported from Pleistocene proximal terminoglacial fans (Ruszczyńska-Szenajch, 1982; Zieliński, 1992). The gravelly diamictons are considered to represent the 'ice-slope zone' (RuszczyńskaSzenajch, 1982), whereas the sandy sediments were deposited in the distal part of the Charlottenthal fan and represent migration of 3-D dunes formed in the deeper part of channels and the plane bed formed in shallow, low-energy currents; the sediments typically accumulated in shallow braided-stream channels in the outer part of the glaciomarginal zone, between the middle and distal parts of a sandur.

Some old, classical definitions of end moraines describe them as containing mainly diamicton/till (Eyles, 1979; Lawson, 1979), but some other definitions recognise that they contain both diamictons and sorted sediments (Woldstedt, 1961; Flint, 1971; Kasprzak, 1988; Zieliński 1992; Dobracki \& Krzyszkowski, 1997; Krzyszkowski \& Zieliński, 2002). In the case of the Charlottenthal fan, both types of deposit are present: sorted sediment at the base and in the middle part of the fan profile, and diamicton in the upper part. Krzyszkowski and Zieliński (2002) distinguished, depending on the balance between mass movement and traction transport, three kinds of fan-type end moraines (A, B \& C). Type A and B end-moraine fans are characterised by a distinct hilly morphology, whereas type $C$ shows a less distinct hilly morphology and extensive widths of 1-2 km or more. The type A end moraine is, according to them, dominated by debris- or mud-flow deposits in the proximal part of the fan, and by deposits from hyperconcentrated flows in the distal part. The type B end moraines are thus built up as a consequence of debris- or grain flows and high-energy sheetfloods in the proximal part, and from sheetfloods in the distal parts (channelized currents are very rare). The type $\mathrm{C}$ end moraine in the proximal part is dominated by sheetfloods and channelized currents (mass flows are extremely rare), and in the distal part by low-energy sheetfloods. This implies that the Charlottenthal fan cannot be considered as an A or B type end moraine (channelized sediments prevail), nor as a $C$ type end moraine (because of the occur- 
Table 2. Comparison of the sediments and depositional processes of the fan under study, with a model of the transitional fan sensu Pisarska-Jamroży (2006).

\begin{tabular}{|c|c|c|c|}
\hline & $\begin{array}{l}\text { Lithofacies } \\
\text { associations }\end{array}$ & Main features of lithofacies associations & $\begin{array}{l}\text { Architectural elements \& depositional } \\
\text { processes }\end{array}$ \\
\hline \multirow{3}{*}{ 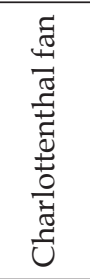 } & $\operatorname{DmC}\left(\mathrm{m}_{2}\right)$ & $\begin{array}{l}\text { - coarse- \& medium-grained diamicton } \\
\text { - matrix-supported } \\
\text { - lenticular layers }\end{array}$ & subaerial debris flows \\
\hline & Gm, Sh & $\begin{array}{l}\text { - massive gravel and horizontally laminated sand } \\
\text { - sheet-like layers }\end{array}$ & sheet flows \\
\hline & St, Sp & $\begin{array}{l}\text { - trough- \& planar cross-stratified sand } \\
\text { - sheet-like layers }\end{array}$ & shallow flows in sandy braided channel \\
\hline \multirow{4}{*}{ 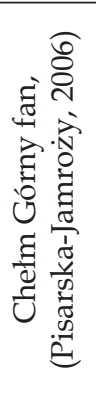 } & $\begin{array}{l}\operatorname{DmC}\left(\mathrm{m}_{3}\right) \& \\
\operatorname{DmM}\left(\mathrm{m}_{3}\right)\end{array}$ & $\begin{array}{l}\text { - coarse- \& medium-grained diamicton } \\
\text { - matrix-supported } \\
\text { - lenticular (lobate) layers }\end{array}$ & subaerial cohesional debris flows \\
\hline & Sh, GPm & $\begin{array}{l}\text { - horizontally laminated sand \& massive gravel } \\
\text { - sheet-like layers } \\
\text { - rhythms: GPm } \rightarrow \text { Sh }\end{array}$ & sheet flows \\
\hline & Sp, GRp & $\begin{array}{l}\text { - planar cross-stratified sand \& gravel } \\
\text { - sheet-like layers }\end{array}$ & $\begin{array}{l}\text { shallow flows in sandy/gravelly } \\
\text { braided channel }\end{array}$ \\
\hline & Sm & $\begin{array}{l}\text { - massive sand } \\
\text { - sheet-like layers }\end{array}$ & hyperconcentrated flows \\
\hline
\end{tabular}

rence of a $1.7 \mathrm{~m}$ thick gravelly diamicton on top) (Fig. 4).

The spatial differentiation of the depositional processes in the Charlottenthal gravel pit clearly reflects its transitional position between the mass-flow-dominated end-moraine ridge (proximal part of the transitional fan) and the fluvial-dominated outwash plain (distal part of the transitional fan).

The sedimentary succession has been compared with the Chełm Górny glaciomarginal fan (NW Poland), which belongs to the same moraine system of the Pomeranian phase (Fig. 3). The deposits in the Chełm Górny pit (Pisarska-Jamroży, 2006) have been divided into four groups (Table 2): (1) a gravelly diamicton deposited by debris flows (massive, with cobbles, boulders and pebbles), (2) sandy diamicts deposited by hyperconcentrated flows (massive sands), (3) sandy to gravelly layers deposited by sheetfloods (horizontally laminated sands and massive pebbly gravels), and (4) sandy and granule gravels deposited by shallow braided streams (planar cross-stratified sands and granule gravels). The sedimentological characteristics of the Charlottenthal deposits and of the transitional fan in Chełm Górny (Pisarska-Jamroży, 2006) both show a dominance of debris-flow and sheetflood deposits, accumulated in the proximal part of the fan, as well as deposits accumulated in shallow channels in the distal part (Table 2). In the middle zone of the Chełm Gorny fan, also deposits from hyperconcentrated flows are present; these are absent in the Charlottenthal pit.

A transitional fan is a morphological unit at a position where an end moraine passes gradually into an outwash plain. The term 'transition-

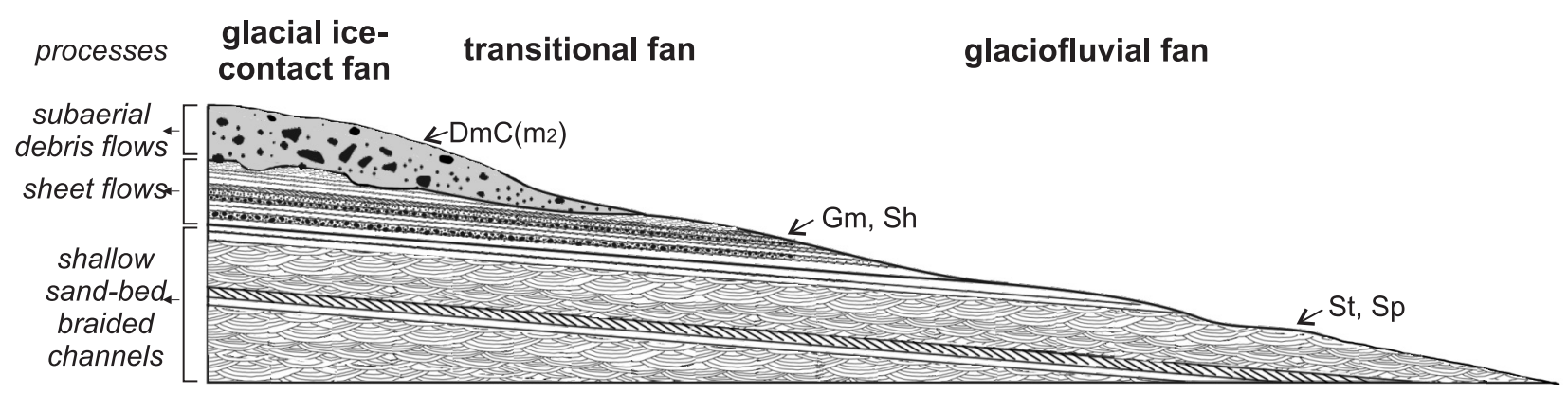

Fig. 7. Model for the transitional-fan subenvironment based on the present study. 
al fan' was first used by Bartkowski (1972), but the first sedimentological investigation of such a fan was carried out in Chełm Górny (NW Poland) by Pisarska-Jamroży (2006). A transitional fan consists of flowtills, massive/stratified gravels and sands, and is dominated by coarsegrained cohesive debris-flow and sheetflood deposits, and by deposits from channelized currents and hyperconcentrated flows.

In summary, the genesis of the deposits in Charlottenthal and Chełm Górny is very similar, and the most likely is that both are part of a transitional fan (Fig. 7).

\section{Discussion}

The clasts in the till constitute a petrographical assemblage that is characteristic of the main Weichselian ice advance in the central part of Mecklenburg-Vorpommern, and it thus indicates that the upper Charlottenthal profile accumulated during the Pomeranian phase of the main Weichselian glaciation. The abundance in Charlottenthal of marls and flints that are derived from the Upper Cretaceous is typical for the so-called 'Kreidemoränen' which occur in NE Germany in tills of several glaciations.

The comparison of indicator pebbles shows similar ice-flow directions (from NNE to SSW) during the Pomeranian ice advance for both the Charlottenthal and the Chełm Górny deposits. The majority of samples show a dominance of Palaeozoic limestones, Scandinavian sandstones and Palaeozoic shales.

The analysis of samples with different grainsize distributions and deposited by different processes poses a following problem. The clear petrographical differences between till samples and glaciofluvial samples from the same profiles indicate that the samples of different depositional histories are not fully comparable each other. The influence of mechanical weathering during high-energy transport in the glaciofluvial environment, causing eventually the disappearance of soft clasts, must be held responsible. The distance of $200 \mathrm{~km}$ between the Charlottenthal and Chełm Górny sites also reduces the value of a detailed petrographical comparison. Considering the above, it seems worthwhile to investigate the influence of the grain-size distribution on the petrographical composition of clasts in tills and in glaciofluvial gravels (cf. Schulz, 1996).

The Charlottenthal fan does sedimentologically resemble neither an end moraine nor an outwash plain. An end moraine typically consist of flowtills and massive/stratified coarse gravels in its proximal part, of massive/stratified sands and gravels in its middle part, and of stratified sands and silts in its distal part. An outwash plain typically consists of stratified gravels and sands deposited by a large braided-river system. The Charlottenthal fan is, however, dominated by deposits from channelised currents, sheetfloods and subaerial debris-flows, and its formation in a fan environment is the most probable.

Sedimentary architecture at the Charlottenthal site is related to the morphology, i.e. the dip angle and dip azimuth of the beds and the laminae are co-directional to the inclined sedimentary surface of fan. A similar style of sedimentation had been recognised earlier in the Pomeranian glaciomarginal zone of NW Poland (Pisarska-Jamroży, 2006, 2008).

\section{Conclusions}

The deposits from Charlottenthal can be grouped into two lithofacies associations and one lithofacies. Lithofacies $\operatorname{DmC}\left(\mathrm{m}_{2}\right)$ represents subaerial debris flows, whereas the gravelly and sandy deposits of lithofacies Gm, Sh jointly represent sheetfloods; the sandy lithofacies St, Sp are together form an association representing braided-stream channels.

Debris-flow deposits derived from supraglacial ablation originally accumulated at the ice front. Gravitation then triggered debris flows. Sheetflood sedimentation can be attributed to seasonal changes in the discharge at the ice-sheet margin.

Comparison of indicator pebbles shows similar ice-flow directions (from NNE to SSW) for the Charlottenthal and Chełm Górny sediments, which both must be ascribed to the Pomeranian phase ice advance. 
The deposits at Charlottenthal are interpreted as characteristic of a transitional zone between an end moraine and a proximal outwash plain (sandur), and thus constitute a 'transitional fan' (sensu Bartkowski, 1972; PisarskaJamroży, 2006, 2008).

\section{Acknowledgements}

We thank J. Winsemann and an anonymous referee for many worthwhile advises. This study was supported by a grant in 2009 from the German Academic Exchange Service DAAD (Deutscher Akademischer Austauschdienst) to the first author.

\section{References}

Bartkowski, T., 1972. Internal structure of marginal zone forms in the area of last glaciation in the Polish Lowland. Sprawozdania Poznańskiego Towarzystwa Przyjaciót Nauk, Wydział Matematyczno-Przyrodniczy 13, 27-67.

Blair, T.C. \& McPherson, J.G., 1994. Alluvial fans and their natural distinction from rivers based on morphology, hydraulic processes, sedimentary processes, and their facies assemblages. Journal of Sedimentary Research A64, 450-489.

Börner, A. \& Müller, U., 2009. Bericht zur lithostratigraphischen Einstufung von Grundmoränen aus der Kiesgrube 'Charlottenthal' [Report on the lithostratigraphical positioning of tills from the 'Charlottenthal gravel pit]. Unpublished report, LUNG M-V, Güstrow, 6 pp.

Bremer, F., 2000. Geologische Übersichtskarte von Mecklenburg-Vorpommern 1:500.000. LUNG M-V, Güstrow.

Dobracki, R. \& Krzyszkowski, D., 1997. Sedimentation and erosion at the Weichselian ice marginal zone near Golczewo, NW Poland. Quaternary Science Reviews 16, 721-740.

Flint, R.F. 1971. Glacial and Quaternary Geology. Wiley, New York, 589 pp.

GFE, 2000. Ergebnisbericht zur Aufsuchung von Quarz und Quarzit (grundeigener Bodenschatz) im Feld Charlottenthal 3 [Report on the exploration of quartz and quartzite in owned-property resources in Charlottenthal 3]. Unpublished report, GKM GmbH, Schwerin, 7 Appendices, 16 pp.

Górska-Zabielska, M. \& Pisarska-Jamroży, M., 2008. Zróżnicowanie petrograficzne plejstoceńskich osadów Pojezierza Myśliborskiego na przykładzie żwirów z Chełma Górnego i Cedyni [Petrographical differentiation of Pleistocene deposits of the Myślibórz Lakeland (Western Pomerania) based on gravels from Chełm Górny and Cedynia]. Przegląd Geologiczny 56, 317-321.

Górska-Zabielska, M., 2008. Fennoskandzkie obszary alimentacyjne osadów akumulacji glacjalnej i glacjofluwialnej lobu Odry [Fennoscandinavian source areas of the glacial and glaciofluvial deposits of the Odra lobe]. Geografia 78, 330 pp.

Harms, J.C., Southard, J.B. \& Walker, R.G., 1982. Structures and sequences in clastic rocks. Short course No. 9 lecture notes, SEPM, Tulsa, $250 \mathrm{pp}$.

Harvey, A.M., 1984. Debris flow and fluvial deposits in Spanish Quaternary alluvial fans: implications for fan morphology. [In:] E.H. Koster \& R.J. Steel (Eds): Sedimentology of gravels and conglomerates. Canadian Society of Petroleum Geologists Memoir 10, 123-132.

Instrukcja, 1996. Instrukcja opracowania i wydania Szczegółowej Mapy Geologicznej Polski w skali 1:50 000 [Instruction for preparation and edition of the Detailed Geological Map of Poland at scale 1:50,000]. PIG Press, Warszawa.

Johnson, A.M. \& Rodine, J.R., 1984. Debris flow. [In:] D. Brundsen \& D.B. Prior (Eds): Slope instability. Wiley, Chichester, 257-361.

Kasprzak, L., 1988. Dyferencjacja mechanizmów formowania stref marginalnych faz leszczyńskiej i poznańskiej ostatniego zlodowacenia na Nizinie Wielkopolskiej [Differentiation of the mechanisms involved in the formation of the marginal zones of the Leszno and Poznan phases of the last glaciation, Great Polish Lowland]. Dokumentacja Geograficzna 5/6, 159 pp.

Krüger, J. \& Kjær, K.H., 1999. A data chart for field description and genetic interpretation of glacial diamicts and associated sediments with examples from Greenland, Iceland, and Denmark. Boreas 28, 386-402.

Krzyszkowski, D. \& Zieliński, T., 2002. The Pleistocene end moraine fans: controls on their sedimentation and location. Sedimentary Geology 149, 73-92.

Lüttig, G., 1958. Methodische Fragen der Geschiebeforschung [Questions on the methodology of the analysis of erratics]. Geologisches Jahrbuch 75, 361-418.

McKee, E.D., Crosby, E.J. \& Berryhill, H.L., 1967. Flood deposits, Bijou Creek, Colorado. Journal of Sedimentary Petrology 37, 829-851.

Miall, A.D., 1977. A review of the braided river depositional environment. Earth-Science Reviews 13, 1-62.

Miall, A.D., 1978. Lithofacies types and vertical profile models in braided river deposits: a summary. [In:] A.D. Miall (Ed.): Fluvial Sedimentology. Canadian Society of Petroleum Geologists Memoir 5, 597-604.Miall, A.D., 1985. Architectural element analysis: a new method of facies analysis applied to fluvial deposits. Earth-Science Reviews 22, 261-308.

Mohrig, D., Heller, P.L., Paola, C. \& Lyons, W.J., 2000. Interpreting avulsion process from ancient alluvial sequences: Guadalope-Matarranya system (northern Spain) and Wasatch Formation (western Colorado). Geological Society of America Bulletin 112, 1787-1803.

Nemec, W. \& Steel, R.J., 1984. Alluvial and coastal conglomerates: their significant features and some comments on gravelly mass-flow deposits. [In:] E.H. Koster \& R.J. Steel (Eds): Sedimentology of gravel and conglomerates. Canadian Society of Petroleum Geologists Memoir 10, 1-31.

Nemec, W., 1990. Aspects of sediment movement on steep delta slope. [In:] A. Colella \& D.B. Prior (Eds): 
Coarse-grained deltas. International Association of Sedimentologists Special Publication 10, 29-73.

Pisarska-Jamroży, M., 2006. Transitional deposits between end moraine and sandur plain in the Pomeranian glacimarginal zone of NW Poland: a missing component of ice-contact sedimentary models. Boreas $35,126-141$.

Pisarska-Jamroży, M., 2008. Zonation of glaciomarginal environment inferred from Pleistocene deposits of Myślibórz Lakeland, NW Poland. Geografiska Annaler 90A, 237-249.

Rühberg, N., Schulz, W., Von Bülow, W., Müller, U., Krienke, H.D., Bremer, F. \& Dann, T., 1995. V. Mecklenburg-Vorpommern. [In:] L. Benda (Ed.): Das Quartär Deutschlands. Berlin, 95-115.

Ruszczyńska-Szenajch, H., 1982. Depositional processes of Pleistocene lowland end moraines, and their possible relation to climatic conditions. Boreas 11, 250-260.

Schulz, W., 1962. Aufnahmebericht zur geologischen Übersichtskartierung 1:100 000: Blatt 2339 - Krakow, mit geologischer Karte 1:25 000. [Report on the general geological mapping 1:100 000: Sheet 2339 - Krakow, with geological map 1:25 000]. Unpublished report, VEB Geologische Erkundung Nord (GFE), Schwerin.

Schulz, W., 1963. Eisrandlagen und Seeterrassen in der Umgebung von Krakow am See in Mecklenburg. Geologie 12, 1152-1168.

Schulz, W., 1996. Zur Bedeutung der Korngröße bei Geschiebezählungen. Der Geschiebesammler 29, 91-102.

Scott, K.M., 1971. Origin and sedimentology of 1969 debris flow near Glendora, California. United States Geological Survey Professional Paper 750-C, 242-247.

Sharp, R.P. \& Nobles, L.H., 1953. Mudflow of 1941 at Wrightwood, Southern California. Geological Society of America Bulletin 64, 547-560.
Smith, N.D., 1970. The braided stream depositional environments: comparison of the Platte River with some Silurian clastic rocks, north-central Appalachians. Geological Society of America Bulletin 81, 2993-3014.

TGL 25232, 1980. Fachbereichsstandard Geologie 25232/0105+06, Analyse des Geschiebebestandes quartärer Grundmoränen [Analysis of the clast content of Quaternary tills]. Zentrales Geologisches Institut, Berlin, 35 pp.

Woldstedt, P. 1961. Das Eiszeitalter. Grundlinien einer Geologie des Quartärs 1. F. Enke, Stuttgart, 374 pp.

Zieliński, T. \& Van Loon, A.J., 1996. Characteristics and genesis of moraine-derived flow till varieties. Sedimentary Geology 101, 119-143.

Zieliński, T., 1992. Moreny czołowe Polski pótnocnowschodniej - osady $i$ warunki sedymentacji [Marginal moraines of NE Poland - sediments and depositional conditions]. Silesian University, Katowice, 95 pp.

Zieliński, T., 1993. Sandry Polski pótnocno-wschodniej-osady $i$ warunki sedymentacji [Outwash plains of NE Poland - sediments and depositional processes]. Silesian University, Katowice, 96 pp.

Zieliński, T., 2003. Czy możliwa jest identyfikacja środowiska glacimarginalnego na podstawie kryterium litologicznego? [Is lithology a useful tool for the recognition of the glaciomarginal environment?] [In:] M. Harasimiuk \& S. Terpiłowski (Eds): Analizy sedymentologiczne osadów glacigenicznych [Sedimentological analysis of glaciogenic sediments]. UMCS Press, Lublin, 95-104.

Manuscript received 15 November 2010 revision accepted 7 March 2011 